\title{
Reideologi Warga Eks HTI: Doktrinisasi Nasionalisme, Moderasi Islam dan Indonesia
}

\author{
Pasiska dan Zainal Azman
}

STAI Bumi Silampari Lubuklinggau, Indonesia

bruspasiska@gmail.com, zainalazman04@gmail.com

\begin{tabular}{ll}
\hline & Abstract \\
\hline Article History & In this paper, we will review the \\
Received:07-09-2020 & phenomena that are present in this nation: \\
Revised :13-09-2020 & this phenomenon is none other than the \\
Accepted:19-09-2020 & existence of a movement that is able to \\
Keywords: & hegemony the community for love for the \\
Keywords: & homeland carried out by former HTI \\
Reideology, & residents, the method used in the research \\
Character education, & is descriptive qualitative research about \\
Nationalism & what happens in everyday life, either in \\
& social media and phenomena that exist in \\
& society. As for the form of Reidology with \\
& the character education approach, the \\
& character education in question combines \\
& the concept of Islamic education in Islamic \\
& schools and education in state defense \\
& whose output gives birth to the nation's \\
& children, especially former HTI residents to \\
& return to love the Republic of Indonesia. \\
& Why is this important to do, so that there \\
& are no longer Indonesian citizens who are \\
& in crisis of nationalism and play an active \\
& role in filling this independence from a \\
development perspective in their own way.
\end{tabular}

\section{Pendahuluan}

Semakin berkembang zaman maka semakin berkembang juga tantangan yang dihadapi terutama masalah ke Islaman, ke Bangsaan dan Ke Indonesiaan. Hal tersebut terecermin pada beberapa fenomena yang terjadi di Indonesia beberapa tahun terakhir seperti dalam ke Islaman sering terjadi Agama digunakan sebagai Alat politik dan kepentingan(FKUB Sebut Agama Masih Jadi Alat Politik di Seluruh 
Dunia | Republika Online t.t.), yang kemudian membuat publik menjadi gempar, kemudian masalah kebangsaan misalnya lemahnya peran diplomasi Indonesia di dunia Internasional dan masalah ke Indonesiaan ada beberapa kelompok kecil di Indonesia ingin memerdekan diri dari Indonesia dan membuat Negara baru yang kesemuanya membuat rakyat menjadi terkonsentrasi pada berbagai persepektif yang tidak lain membuat kepercayaan public menurun kepada pemerintahan hingga ada rasa keraguan kepada Ideologi Negara(Wiranto Desak Organisasi Kontra-Pancasila Dibubarkan Tirto.ID t.t.).

Karena meragukan ideology Negara maka acap sekali mengkritisi bahwa Ideologi Negara bukan inspirasi dan bersumber kepada ajaran Agama, maka dari itu wajib diubah menjadi ideology tertentu yang sejalan dengan konsep ideology tertentu yang tujuannya tidak lain akan membuat NKRI akan menjadi terpecah-pecah dan hancur (6 Gerakan Memisahkan Diri dari Indonesia yang Pernah Terjadi - Boombastis.com | Portal Berita Unik | Viral | Aneh Terbaru Indonesia t.t.), salah satunya ormas yang dimaksud yakni Hizbut Tahrir Indonesia (HTI) melakukan gerakan doktrinasi Ideologi HTI memang masiv dan bahkan sudah merabah keseluruh lapisan masyarakat, mulai dari masyarakat biasa seperti buruh, tani, dan bahkan pegawai pemerintahan atau PNS sudah ada yang menjadi partisipan serta menjadi tokoh HTI (PNS Linggau Jadi Simpatisan HTI - Metro Sumatera t.t.), hal itu menjadi pekerjaan rumah bersama bagi anak umat dan bangsa yang hari ini hidup dan tinggal di negeri nusantara.

Maka disinilah dituntut peran pemerintah yang harus ekstra perhatian dalam usaha menyatukan kembali anak negeri yang sudah berupaya untuk melepaskan diri dari NKRI, sebut saja pada zaman dahulu ada kelompok yang menamakan Negara Islam Indonesia, Kemudian ada lagi gerakan di Sumatera seperti Gerakan Aceh Merdeka (GAM)(GAM Lahir demi Kedaulatan atas Kekayaan Alam Aceh - Tirto.ID t.t.), Organisasi Papua Merdeka (OPM)(Kelahiran OPM: Gerakan Spiritual Rahasia hingga Angkat Senjata t.t.), kemudian disusul oleh hadirnya pelaku teroris di Indonesia mulai terjadi pengeboman disana sini wilayah Indonesia(7 Serangan Teroris di Indonesia Tiga Tahun Terakhir, Nomor 5 Diwarnai 'Drama': Okezone Nasional t.t.), dan fenomena lain yang ingin memecah belahkan NKRI, cukup saja Timor Timur yang lepas dari 
NKRI(Sejarah \& Kronologi Timor Timur Lepas dari RI yang Diungkit Prabowo - Tirto.ID t.t.) sebagai pelajaran sebagai lemahnya pengawasan pemerintah akan wilayah Indonesia ini, dan kedepan jangan ada lagi perpecahan lagi, demi Nasionalisme kebangsaan Indonesia, untuk itu perlunya peran pemerintah yang kongkrit agar kedepan tidak terjadi lagi kasus krisis Nasionalisme keIndonesiaaan, jangan sampai terjadi lagi tragedi yang buruk apa lagi NKRI hancur oleh segelintir kepentingan dan oleh segelintir organisasi, dan pemerintah harus membuat sebuah kebijakan yang mampu membangun rasa memiliki dan mencintai Indonesia dengan segala yang ada, serta dibarengi dengan kinerja pelakanaan pemerintah yang baik dan bersih agar kebijakan pemerintah menasionalisme anak bangsa dapat tercapai, kemudian program tersebut mau tidak mau harus tersosialisasi kepada seluruh anak bangsa agar tidak ada lagi keinginan anak bangsa keluar dari NKRI atau bahkan mengahancurkan NKRI.

\section{Metode Penelitian}

Pada Penelitian yang digunakan ini adalah dengan jenis penelitian kualitatif deskriptif. $(2005,36)$ Sedangkan dilihat dari tempat pengolahan datanya atau sumber datanya penelitian ini adalah penelitian kepustakaan (Library Research). penelitian yang datanya diambil sebagian atau keseluruhan dari perpustakaan, contohnya artikel, laporan, buku-buku, koran, dan lain-lain”. (2005, 36). Adapun prosedur penelitian yang akan dilakukan pertama mengumpulkan literatur-literatur mengenai Ibnu Khaldun kemudian setelah dikumpulkan maka peneliti memilah dan memilih yang mana yang dapat digunakan untuk penelitian terkait tema penelitian yang akan diangkat. Lalu disitulah peneliti mulai untuk mengumpulkan data dengan cara dokumentasi.

Pendekatan yang digunakan dalam penelitian ini kajian isi, analisis data dimaksudkan untuk menemukan unsur-unsur atau bagian-bagian yang berisikan kategori yang lebih kecil dari data penelitian (Moleong 1989, 147) . Kegiatannya adalah mengolah data agar dapat difahami dengan lebih baik sebagaimana yang dikatakan Miles dan Huberman dengan mereduksi data, yaitu proses pemilihan, memfokuskan pada penyederhanaan, pengabstraksian dan transformasi data mentah yang muncul dari hasil temuan dari proses penelitian literatur. Kemudian peneliti melakukan Reduksi data 
merupakan suatu bentuk analisis yang menajamkan hal-hal yang penting, menggolongkan, mengarahkan, membuang yang tidak dibutuhkan dan mengorganisasikan data agar lebih sistematis sehingga dapat dibuat suatu kesimpulan (Miles dkk. 1994, 16) .

\section{Pembahasan}

\section{Kilasan Perjalanan HTI dan Pasca dibubarkan}

Kita tau bahwa salah satu organisasi yang menjadi pusat perhatian mata masyarakat Indonesia yang keras meyuarahkan bahwa negara Indonesia menggunakan sistem Thogut dan bukan sistem Islam dan harus diganti dengan sistem Islam yakni Khilafah (mengapa hti layak dibubarkan? - kumparan.com t.t.), ya organisasi tersebut yakni Hizbut Tahrir Indonesia yang sudah tidak asing bagi masyarakat Indonesia ini, setelah pada masa pemerintahan Jokowi, melalui Kementrian Hukum dan Hak Asasi Manusia mengeluarkan untuk menertibkan organisasi yang mengancam Ideologi Pancasila(PERPU No. 2 Tahun 2017 tentang Perubahan Atas Undang-Undang Nomor 17 Tahun 2013 Tentang Organisasi Kemasyarakatan [JDIH BPK RI] t.t.) yang memutuskan melalui Kemetrian Hukum dan HAM : menyatakan untuk membubarkan organisasi Hizbut Tahrir Indonesia (HTI), alasannya tidak lain HTI tidak memberikan peran dalam pembangunan Nasional dan menentang Ideologi Negara Indonesia serta membuat ketidak stabilan keamanan Nasional. Maka secara Konstitusional HTI dibubarkan dan dianggap sebagai organisasi yang menentang ideologi Pancasila (Pemerintah Tegaskan Ideologi Khilafah Bertentangan dengan Pancasila t.t.), setelah resmi dibubarkan dan menjadi organisasi terlarang maka secara keorganisasian tidak boleh ada lagi aktivitas yang berkenanan apapun di organisasi tersebut, nah kemanakah warga pengurus HTI secara keorganisasian telah dibubarkan tersebut, secara psikis warga eks HTI merasa kaget dan bahkan tertekan akan keputusan yang buatkan oleh pemerintah tentang pembuburan organisasi HTI secara konstitusional, dan pada posisi lain justru membangkitkan semangat mereka untuk tetap istiqomah dalam menyiarkan ajaran Khilafah yang menjadi persepektif perjuangan yang dijadikan dasar untuk memberikan pemahaman tentang kekhalifahan.

Fenomena itu tidak berhenti hanya pada sampai pada hegemoni yang biasa-biasa saja bahkan membentuk semacam forum diskusi 
atau organisasi lain yang dibentuk dengan penamaan lain akan tetapi dengan sebuah visi dan misi yang sama, hanya saja bentuk secara fulgar tidak ditampakkan secara jelas sebut saja misal organisasi yang fenomela tersebut seperti Indonesia Tanpa Pacaran(Indonesia Tanpa Pacaran t.t.), Yuk Ngaji(YukNgaji ${ }^{\mathrm{TM}}$ Regional Jogja (@yukngajijogja) • Foto dan video Instagram t.t.), Fast Hijrah (FAST - Hijrah Community t.t.), Majelis Cinta Nabi Cinta Syari'ah(Cinta Nabi Cinta Syari'ah - Meneladani Kehidupan Rasulullah t.t.). Organisasi tersebut bisa besar dan kuat karena didukung oleh tokoh yang terus aktif mengkampanyekan dakwah kekhalifahan seperti Ismail Yusanto, Felix Y Siaw, Laode Munafar. Dan terus dikampanyekan dengan gaya yang lebih mudah diterima oleh anak muda milenial.

Strategi yang digunakan untuk mengcover gaya hidup anak muda yang sedang mencari jati diri adalah dengan membuat konten dimedia social seperti youtube Indoesia Tanpa Pacaran(IndonesiaTanpa Pacaran - YouTube t.t.), Yuk Ngaji(YukNgaji ID - YouTube t.t.), Instagram, Facebook dan grup Whatsapp, mudah difahami dan muda dimenegrti anak muda serta tetap sasaran, ditambah lagi dalam kajian yang dibuat seperti kelaskelas tertentu, ada yang kelas eksekutif, ada yang kelas Fast dan lainnya sesuai dengan kemampuan Budgeting anak muda yang ikut kegiatan tersebut, selain dari pada ngaji atau belajar yang gunakan secara klasikal ada juga cara lain pendekatan untuk merekrut dan memahamkan visi misi organisasi tersebut yakni dengan Hangout baik di Cafe, Hotel dan bahkan ada kelas namanya tadabur alam, seperti camping ditempat-tempat yang sudah ditentukan.

Hal itu banyak diminati oleh banyak kalangan anak muda dikarenakan anak muda suka dengan hal-hal yang menyenangkan seperti refresing ke tempat-tempat yang kekinian, café dan hal-hal yang menyenangkan, atau sering disebut gaya hidup, traveling, makan-makan dan update status di medsos, dan tidak sedikit juga mendapatkan respon positif dibuktikan dengan banyaknya pengikut atau Followers dan program yang dibuat juga banyak yang mengikuti dan sasaran yang paling cepat adalah anak muda yang sedang mencari jati diri. 


\section{Orientasi warga HTI setelah dibubarkan}

Kilasan perjalanan perjalanan HTI diatas dan pada ketika dibubarkannya organisasi tersebut secara konstitusional maka sebuah pertanyaan besar yakni kemanakah mereka, dan apa yang mereka lakukan ketika tidak lagi organisasi secara konstitusional yang menaungi, sederhananya ketika HTI dibubarkan maka organisasi tersebut resmi tidak bisa beraktifitas lagi dengan kata lain organisasi "HTI" ini organisasi terlarang, sebab dapat mengancam kedaulatan idelologi Pancasila yang sejatinya sebagai idelogi Negara Kesatuan Republik Indonesia, namun secara keaktifitas lainnya masih dlakukan secara normal-normal saja, ketika melihat pada sebuah orientasi yang dilakukan terutama ketika selesainya organisasi HTI resmi dibubarkan dan mereka tetap melangsungkan kajian-kajian tentang kekhilafahan, dan semangat untuk memperjuangkan Khilafah dalam persepektif HTI masih saja dan malah dengan semangat yang lebih tinggi misalnya melakukan sosialisasi, penyebaran dengan menggunakan media sosial dan dibentuk dengan sedemikian rupa seperti kajian, Share Kajian Muslimah(Share Kajian Muslimah (@sharekajianmuslimah)• Instagram photos and videos t.t.), dan lainnya seperti yang sudah diulas diatas.

Bahkan sudah memperediksikan bahwa ajaran Khilafah akan tegak di Indonesia pada tahun 2020(Media Kaffah - Beranda t.t.) dan mampu menganggantikan ideologi Pancasila, yang kemudian memancing semangat kembali para kader dan anggota HTI, untuk tetap berkomitmen dengan prinsip memperjuangkan konsep pemerintahan khilafah, hal itu diasumsikan bahwa islam mayoritas penduduknya adalah beragama Islam akan tetapi bentuk negara tidak Islam atau Demokrasi dan Ideologi yang dipakai dalam Negara Ideologi Pancasila bukan Al-Qu'an hal itulah menambah semangat yang militan bagi masyarakat pernah ikut dan menjadi kader HTI, hal itu tidak lain melihat kondisi yang ada di Arab Saudi misalkan menggunakan konsep Islam dan menjadikan Idelologi serta konsep pemerintahan Islam Monarki Absolut, seperti kelihatan secara sekilas Arab negeri yang aman damai, makmur serta mampu mengakomodir rakyat dengan sistem tersebut dan sampai sekarang masih eksis dengan konsep Negara Islam Khilafah persepektif HTI.

Bila dibiarkan saja maka NKRI sekarang dan akan datang dapat terpecah bela bukan tidak mungkin, provinsi-provinsi lain di Indonesia akan mencoba melepaskan diri dari wilayah Kedaulatan 
NKRI, terutama provinsi mayoritas penduduknya non Muslim atau mayoritas Muslim, karena bisa saja terinspirasi dari garakan yang ingin mengubah negara Indonesia menjadi negara Islam secara Kaffah persepektif sistem pemerintahan Khilafah, dan pada akhirnya sirna sudah perjuangan para pendiri bangsa ini yang berusaha untuk memajukan serta melihat Indonesia kedepan menjadi bangsa yang besar (Pendiri Bangsa Bercita-cita Bentuk Negara Adalah NKRI Nasional JPNN.com t.t.) yang dimulai dari semangat atas sama rasa senasib sepenanggungan yakni pernah merasakan pahitnya dijajah para kolonialisme dan mendirikan kedaulatan Negara ketika masa dijajah bukan main sulitnya, nah bisa saja hancur oleh kepentingankepentingan yang berusaha untuk memecah-belahkan NKRI.

\section{Doktrinasi Nasionalisme dan Moderasi Islam}

Pemerintah tentu saja tidak menginginkan anak bangsa ini menjadi terpecah bela dan bahkan melawan negara, dengan segala macam bentuk dan cara yang digunakan, mulai melalui cara politik agama, propaganda kepada masyarakat, baik dimedia cetak, media online, media sosial hal itu tidak lain merupakan bentuk ekspresi diri dari kelompok tertentuyang menganggap bahwa yang termarginal, baik secara kemandirian ekonomi, maupun kemandirian lainnya, untuk itu perlu perhatian serius kepada fenomena yang terjadi tersebut, bila dibiarkan dari kecil bisa saja menjadi besar, dan pada akhirnya menjadi masalah bagi negara ini, sebab bukan tidak mungkin bisa menghancurkan dan memecah-belakan negara yang sejatinya hal itu tidak perlu terjadi sebab akan banyak hal dapat dirugikan dan pihak asing bahkan ada yang senang bila Indonesia ini menjadi terpecah bela, agar tidak terulang kembali hal menghancurkan NKRI maka perlu keseriusan yang kongkrit dari pemerintah akan hal ini, dengan cara membuat semacam kebijakan dan disokong oleh kompetisi yang mumpuni, seperti memberdayakan lembaga pendidikan atau badan khusus untuk menanamkan kembali rasa Nasionalisme kepada kelompok yang selama ini tidak sejalan dengan konsep pemerintahan yang ada di Indonesia.

Konsep penenaman rasa Nasionalisme itu dapat dilalui dengan cara-cara pendidikan yang selama ini efektif dan efesien dalam upaya mengembalikan kembali rasa memiliki akan Negeri Indonesia ini dan sudah dilakukan oleh organisasi Islam tersebesar di Inodnesia yakni Nahdatul Ulama (NU) dan Muhammadiyah, konsep penanaman 
nasionalisme yang di gunakan Organisasi NU seperti Habbul Wathon Minal Iman(Saleh 2013, 4) cinta kepada negara sebagian dari iman yang dimanifestasikan dengan kegiatan kongkrit, seperti melakukan pelatihan dan pendidikan "Bela Negara"(Farih 2016, 251) dan kosnep-kosep tersebut digunakan dan diajarkan kepada santri-santri yang mayoritasnya ada di pondok pesantren, kemudian bukan hanya itu pada kader muda NU misalkan seperti GP Ansor dan lainnya konsep rekrutmen dan pola pendidikan kadernya mengedepankan cinta tanah air(Sanusi dan Darmawan 2016, 24) dan semangat tersebut dipupuk dan dibina oleh para petinggi organisasi dan peran ketokohan sang kyai(Mukhroji 2011, 357) secara totalitas menggiring agar jangan sampai kader dan anggota tidak memiliki semangat nasionalisme, proses penanaman itu miali dari sekolah-sekolah milik organisasi NU dari muali pendidikan dasar hingga pada pendidikan tinggi sekalipun.

Begitu juga sama halnya dengan organisasi Muhammadiyah merawat nasionalisme melalui pendidikan bahwa cinta kepada tanah air melalui pendidikan(Yanyan Hardiana, Dadang Supardan 2016, 1) ssebab dengan banyaknya orang-orang disuatu bangsa dan sadar akan pendidikan akan negara tersebut akan kuat serta disegani, maka konsep muhammadiyah banyak membangun sekolah dan universitas yang pada akhirnya melahirkan manusia yang memiliki sikap pluralitas(Burhani 2018, 433), media penyampainnya melaui pendidikan serta di organisasi semi otonom mereka seperti Pemuda Muhammadiyah yang konsep pendidikan Nasionalisme pada negara yakni Kokam, kemudian ada organisasi perempuan Muhammdiyah yakni Aisyah yang juga aktif memberikan kontribusinya, dan pada akhirnya semangat cinta terhadap Tanah air tinggi karena sudah terbentuk tersistem dan mengakar menjadi budaya, sebab pemahaman yang disampaikan tentang kecintaan dan perjuangan akan tanah air terus dilakukan dan disampaikan.

Selain dari pada itu ulasan kedua organisasi yang Islam terbesar di Indonesia tersebut, kiranya diperlukan strategi kongkrit yang dapat menenamkan pemahaman terhadap nasionalisme ke Indonesiaan yang bingkainya adalah ideologi Pancasila, guna nya tidak lain adalah menanggulangi dan antisipasi serta proses rehabilitasi bagi kelompok tertentu yang ingin dan bahkan mengganti Pancasila sebagai ideologi dengan konsep ideologi lain seperti Khilafah, atau Negara Islam Indonesia, atau negara Indosenia yang berideologi selain Pancasila. 
Hal itu juga berlaku misalkan kepada masyarakat Eks HTI yang notabenenya masih menyimpan rasa dan keinginan akan mendirikan Negara Khilafah di Indonesia ini, walaupun secara keorganisasian tidak ada lagi dan keyakinan besarnya cukup tinggi dengan semangat yang membara akan dapat memperjuangakan negara Khilafah dalam persepektif mereka.

Untuk itu langkah serius yang dilakukan seharusnya pemerintah tidak lain mereideologi masyarakat yang pernah terlibat aktif di Orgaisasi HTI, itu dilakukan disetiap daerah yang ada di Indonesia ini yang kebanyakan didominasi anak muda seperti siswa dan mahasiswa serta, pemuda pasca aktif berkuliah dan kebanyakan mereka yang sibuk mencari ekspresi diri dan mencari jati diri.

Reidelologi yang dilakukan yakni dengan melaui pendidikan, pendidikan yang dimaksud merupakan pembinaan secara khusus bagi anak bangsa yang pernah terlibat dalam HTI, dinataranya pendidikan yang dilakukan seperti Sekolah Ideologi, atau Training Idelologi, atau lebih dikenal akrab perkaderan Idologi. Pada prosesnya atau pelaksanaannya pendidikan mirip-mirip perkaderan pada organisasi mahasiswa Seperti HMI, PMII, IMM, KAMMI, GMNI dan lain sebagainya pola perkaderan atau pendidikan tersebut dengan cara menjauhkan mereka dari kerumunan orang banyak atau masyarakat sipil, bisa saja di inapkan di kamping tenda-tenda di suatu perkemahan, bisa saja pondok pesantren dan atau bisa saja menggunakan fasilitas militer yang amat ekslusif dan jauh dari jangkauan sipil, dengan rentan waktu yang ditentukan seperti 1 minggu, 1 bulan, satu semester, 1 tahun dan bahkan kaderisasi seumur hidup. Dengan kurikulum atau silabus tertentu yang disusun secara format pendidikan atau training berdasarkan waktu yang ditentukan: Adapun bentuk silabus Reidologi sebagai berikut:

\begin{tabular}{|l|l|l|}
\hline No & Nama Materi & Waktu \\
\hline 1. & Sejarah Islam & 6 jam \\
\hline 2. & Sejarah Perjuangan Indonesia 1 & 6 jam \\
\hline 3. & Sejarah Perjuangan Indonesia 2 & 6 jam \\
\hline 4. & $\begin{array}{l}\text { Nasionalisme, keIndonesiaan dan } \\
\text { keIslaman }\end{array}$ & 10 jam \\
\hline 5. & Filsafat Pancasila & 6 jam \\
\hline 6. & Ulama, Bangsa dan Negara filar NKRI & 10 jam \\
\hline
\end{tabular}

Sebagian besar pendidikan yang dilakukan oleh organisasi besar mahasiswa tersebut mampu dan melahirkan kader-kader yang cinta akan Indonesia dengan semangat nasionalisme yang tinggi yang 
sudah mengakar karena pada proses kaderisasinya dilakukan dengan cara tertentu didesain sesuai dengan kebutuhan anak muda terutama mahasiswa dan output yang dihasilkan melahirkan sosok manusia yang berpandangan nasionalisme ke Indonesiaan, kritis, analitik dan berkarakter, tentu saja keberhasilan tersebut tidak lain dari proses pembentukan intelektulaitas melalui perkaderan atau pendidikan yang dilakukan secara berjenjang secara tersistem dan efektif.

Tujuan akhir pada prosesi Reidiologi dengan pendekatan pendidikan tidak lain menginnginkan anak bangsa kembali cinta terhadap tanah air yang dimanefestasikan dalam kehidupan seharihari dan menjadikan Islam sebagai ajaran sekaligus inspirasi untuk membangunkan mengembangkan potensi diri dalam rangka cinta terhadap tanah air, dan ketika nilai-nilai KeIslaman, KeIndonesiaan sudah mendarah daging bukan tidak mungkin rasa cinta dan semanagat Nasionalisme akan muncul dan siap mendjadikan pribadi yang baik dalam kehidupan berbangsa dan bernegara.

Guna tidak terjadi lagi lahirnya generasi yang tidak cinta tanah air bekal tersebut juga salah satunya pendidikan karakter dengan belandaskan nilai-nilai agama, dilain sisi guna mewujudkan manusia Indonesia ini kedepan yang lebih memiliki karakater perlunya perhatian dan dukungan dari semua pihak tertama dalam menanamkan nilai pendidikan karakter baik disekolah, keluarga, lingkungan tempat tinggal dan pemerintah agar generasi yang diharapkan mampu membangun bangsa ini sesuai dengan apa yang diharapkan dan dicita-citakan bangsa ini. Implementasi dari penanaman nilai-nilai Islam mulai menampakkan sisi negativenya, tidak lain untuk menjadikan Insan Indonesia cerdas komprehensif dan kompetitif yakni cerdas spiritual: beraktualisasi diri melalui olah hati untuk menumbuhkan dan memperkuat keimanan, ketakwaan dan akhlak mulia termasuk budi pekerti luhur dan kepribadian unggul. Cerdas emosional dan sosial: beraktualisasi diri melalui olah rasa untuk meningkatkan sensitivitas dan apresiasivitas akan kehalusan dan keindahan seni dan budaya, serta kompetensi untuk mengekspresikannya. Beraktualisasi diri melalui interaksi sosial yang membina dan memupuk hubungan timbal balik, demokratis, empatik dan simpatik menjunjung tinggi hak asasi manusia ceria dan percaya diri menghargaikeberagaman dalam bermasyarakat dan bernegara, serta berwawasan kebangsaan dengan kesadaran akan hak dan kewajiban warga negara. Cerdas intelektual: beraktualisasi diri 
melalui olah pikir untuk memperoleh kompetensi dan kemandirian dalam ilmu pengetahuan dan teknologi, Aktualisasi insan intelektual yang kritis, kreatif dan imajinatif. Cerdas kinestetik: beraktualisasi diri melalui olah raga untuk mewujudkan insan yang sehat, bugar, berdaya-tahan, sigap, terampil(Pasiska 2019, 123-123).

\section{Simpulan}

Fenomena gerakan mendirikan Khilafah yang dinginkan oleh kelompok HTI tidak lain sebuah gerakan yang menciderai semangat cinta tanah air, ketika dibubarkannya organisasi HTI secara konstitusional maka secara keorganisasian HTI resmibubar namun, fenomna lain muncul warga Eks HTI masih menyimpan pendidikan keorganisasian HTI yang masih melekat dan bahkan mendarah daging, untuk mengantisipasi terjadinya grakan perlawanan terhadap NKRI maka upaya yang dilakuakan yang harus ditempuh melakukan pembinaan melalui pendidikan Karakter, Keindonesiaa, Keislaman melalui pendekatan integrasi pendidikan Pesantren dan pendidikan Bela Negara. Tujuan akhir pada prosesi Reidiologi dengan pendekatan pendidikan tidak lain menginnginkan anak bangsa kembali cinta terhadap tanah air yang dimanefestasikan dalam kehidupan sehari-hari dan menjadikan Islam sebagai ajaran sekaligus inspirasi untuk membangunkan mengembangkan potensi diri dalam rangka cinta terhadap tanah air, dan ketika nilai-nilai KeIslaman, KeIndonesiaan sudah mendarah daging bukan tidak mungkin rasa cinta dan semanagat Nasionalisme akan muncul dan siap mendjadikan pribadi yang baik dalam kehidupan berbangsa dan bernegara. 


\section{DAFTAR PUSTAKA}

"6 Gerakan Memisahkan Diri dari Indonesia yang Pernah Terjadi Boombastis.com | Portal Berita Unik | Viral | Aneh Terbaru Indonesia." Https://www.boombastis.com/gerakanmemisahkan-diri/53809 (Maret 18, 2020).

"7 Serangan Teroris di Indonesia Tiga Tahun Terakhir, Nomor 5 Diwarnai 'Drama': Okezone Nasional." Https://nasional.okezone.com/read/2018/05/14/337/1897942/7serangan-teroris-di-indonesia-tiga-tahun-terakhir-nomor-5diwarnai-drama (Maret 24, 2020).

Burhani, Ahmad Najib. 2018. "Pluralism, liberalism and islamism: Religious outlook of Muhammadiyah." Studia Islamika 25(3): 433-70.

"Cinta Nabi Cinta Syari'ah - Meneladani Kehidupan Rasulullah." Https://cintanabicintasyariah.com/ (Maret 18, 2020).

Farih, Amin. 2016. "Nahdlatul Ulama (Nu) Dan Kontribusinya Dalam Memperjuangkan Kemerdekaan Dan Mempertahankan Negara Kesatuan Republik Indonesia (NKRI)." Walisongo: Jurnal Penelitian Sosial Keagamaan 24(2): 251.

"FAST - Hijrah Community." Https://fastport.ngefast.id/home (Maret $18,2020)$.

"FKUB Sebut Agama Masih Jadi Alat Politik di Seluruh Dunia Republika Online." Https://nasional.republika.co.id/berita/nasional/politik/ptjvf637 7/fkub-sebut-agama-masih-jadi-alat-politik-di-seluruh-dunia (Maret 18, 2020).

"GAM Lahir demi Kedaulatan atas Kekayaan Alam Aceh - Tirto.ID." Https://tirto.id/gam-lahir-demi-kedaulatan-atas-kekayaan-alamaceh-camc (Maret 24, 2020). 
"Indonesia Tanpa Pacaran." Https://indonesiatanpapacaran.com/ (Maret 18, 2020).

"indonesiatanpa Pacaran - youtube." Https://www.youtube.com/channel/UCR1NnXBQMLmy3irzkdadpw (Maret 18, 2020).

"Kelahiran OPM: Gerakan Spiritual Rahasia hingga Angkat Senjata." Https://news.detik.com/berita/d-4345011/kelahiran-opmgerakan-spiritual-rahasia-hingga-angkat-senjata (Maret 24, 2020).

"Media Kaffah - Beranda." Https://www.facebook.com/mediakaffah/ (Maret 23, 2020).

"mengapa HTI layak dibubarkan? - kumparan.com." Https://kumparan.com/kesadaran-adalah-matahari/mengapa-htilayak-dibubarkan-1500553285007 (Maret 24, 2020).

Miles, Matthew B., A. Michael Huberman, Michael A. Huberman, dan Prof Michael Huberman. 1994. Qualitative Data Analysis: An Expanded Sourcebook. SAGE.

Moleong, Lexy J. 1989. Metodologi penelitian kualitatif. Remadja Karya.

Mukhroji, Mukhroji. 2011. "Kepemimpinan Kyai Dalam Pengasuhan Pesantren." INSANIA: Jurnal Pemikiran Alternatif Kependidikan 16(3): 358-68.

Pasiska, Pasiska. 2019. "PENDIDIKAN NILAI-NILAI ISLAM DI ERA GLOBALISASI." Journal of Research and Thought on Islamic Education 2(1): 107-125-125.

"Pemerintah Tegaskan Ideologi Khilafah Bertentangan dengan Pancasila."

Https://nasional.kompas.com/read/2017/05/12/16005001/pemer intah.tegaskan.ideologi.khilafah.bertentangan.dengan.pancasila (Maret 18, 2020). 
"Pendiri Bangsa Bercita-cita Bentuk Negara Adalah NKRI - Nasional JPNN.com." Https://www.jpnn.com/news/pendiri-bangsabercita-cita-bentuk-negara-adalah-nkri (Maret 23, 2020).

"PERPU No. 2 Tahun 2017 tentang Perubahan Atas Undang-Undang Nomor 17 Tahun 2013 Tentang Organisasi Kemasyarakatan [JDIH BPK RI]." Https://peraturan.bpk.go.id/Home/Details/53279/perpu-no-2tahun-2017 (Maret 18, 2020).

"PNS Linggau Jadi Simpatisan HTI - Metro Sumatera." Http://www.metrosumatera.com/waduh-pns-linggau-jadisimpatisan-hti/ (Maret 18, 2020).

S. Margono. 2005. Metodologi Penelitian Pendidikan. Jakarta: Rineka Cipta.

Saleh, Zainal Abidin Amir dan Imam Anshori. 2013. Soekarno dan NU: Titik Temu Nasionalisme. Yogyakarta.

Sanusi, Aris Riswandi, dan Cecep Darmawan. 2016. "Implementasi Pendidikan Politik Dalam Membentuk Karakter Kepemimpinan Lintas Budaya Pada Generasi Muda Demi Mewujudkan Budaya Politik Pancasila (Studi Deskriptif terhadap Organisasi Kepemudaan Gerakan Pemuda Ansor Jawa Barat)." Jurnal Pendidikan Ilmu Sosial 25(1): 24.

"Sejarah \& Kronologi Timor Timur Lepas dari RI yang Diungkit Prabowo - Tirto.ID.” Https://tirto.id/sejarah-kronologi-timortimur-lepas-dari-ri-yang-diungkit-prabowo-dcji (Maret 24, 2020).

"Share Kajian Muslimah (@sharekajianmuslimah)•Instagram photos and videos." Https://www.instagram.com/sharekajianmuslimah/ (Maret 23, 2020).

"Wiranto Desak Organisasi Kontra-Pancasila Dibubarkan - Tirto.ID." Https://tirto.id/wiranto-desak-organisasi-kontra-pancasiladibubarkan-cn41 (Maret 18, 2020). 
Yanyan Hardiana, Dadang Supardan, Didin Saripudin. 2016. "Pembelajaran Sejarah Gerakan Nasional Kemuhammadiyahan Untuk Menggali Nilai-Nilai Nasionalisme Peserta Didik" (Studi Naturalistik Inkuiri di SMA Muhammadiyah Kota Tasikmalaya)." Factum, Universitas Pendidikan Indonesia 5: $1-22$.

"YukNgaji ID - Y YouTube." https://www.youtube.com/channel/UCdUvqj7cjMjUcpE_gKgq 43g (Maret 18, 2020).

"YukNgaji ${ }^{\mathrm{TM}}$ Regional Jogja (@yukngajijogja) • Foto dan video Instagram." https://www.instagram.com/yukngajijogja/?hl=id (Maret 18, 2020). 